\title{
COMPARISON OF PHORETIC MITES ASSOCIATED WITH BARK BEETLES Ips typographus AND Ips cembrae FROM CENTRAL CROATIA
} USPOREDBA FORETIČKIH GRINJA NA POTKORNJACIMA
Ips typographus I Ips cembrae U SREDIŠNJOJ HRVATSKOJ

\author{
Stefan F. WIRTH'1 ${ }^{1}$ Olivia WEIS², Milan PERNEK ${ }^{3}$
}

\begin{abstract}
Summary
In different locations of Croatia (Nova Gradiška, Koprivnica, Gospić and Jastrebarsko) adults and developmental stages of Ips cembrae, the large larch bark beetle, and Ips typographus, the European spruce bark beetle, were collected from Picea abies, Larix decidua und Pinus sylvestris together with substrate from their breeding galleries and examined for phoretic mites. Four different mite species were identified by collecting specimens directly from the beetles:

Iponemus gaebleri (Tarsenomidae), Histiostoma piceae (Astigmata, Histiostomatoidea), Dendrolaelaps quadrisetus (Gamasina) and Urobovella sp. (Uropodidae). I. gaebleri was the most abundant mite on both beetle species.

Three other mite species have been collected directly from bark beetle galleries. We also studied the attachmentareas of phoretic mites on their beetle carriers. I gaebleri and D. quadrisetus preferred the elytral declivity, while the phoretic deutonymphs of the Histiostomatidae commonly were found on the ventral side of the thorax.

We discovered statistically significant differences concerning the total of attached mites and a clear preference of I. gaebleri for I. cembrae.

Young callow adults of Ips cembrae, emerging from their maternal galleries carried significantly more phoretic mites than parental beetles, which were picked out of their breeding galleries.

Females of an another species of genus Histiostoma were found in galleries of I. typographus. They all were largely covered by great numbers of two-chamber spores of a fungus belonging to the Ascomycota (Hypocreales).

A dichotomous key to identify larvae and protonymphs of the Histiostomatidae is provided.

KEY WORDS: Coleoptera, Curculionidae, Scolytinae, Tarsenomidae, Histiostomatidae, Acari, Iponemus gaebleri, Histiostoma piceae, Bonomoia pini, Croatia, key to larvae and protonymphs of Histiostomatidae
\end{abstract}

\section{INTRODUCTION}

\section{UVOD}

Galleries of bark beetles (Coleoptera, Curculionidae, Scolytinae) are well known for their remarkable biodiversity of mites (e.g. (Scheucher 1957; Lindquist 1969). Some specialized phoretic species of Gamasina, Trombidiformes, Oribatida and Astigmata are phoretically carried by bark beetles or other inhabitants of bark beetle galleries. Free living instars are often found inside the gallery substrates (Pernek et al. 2012).

\footnotetext{
'Dr. sc. Stefan F. Wirth, Tyumen State University, Russia, wirthstef@web.de

${ }^{2}$ Olivia Weis, Free University of Berlin, Germany

${ }^{3}$ Dr. sc. Milan Pernek, Croatian Forest Research Institute. HR-10450 Jastrebarsko, Croatia, milanp@sumins.hr
} 
The interactions of organisms associated with Scolytinae are sometimes even more complex than being strictly based on phoresy or parasitism. In case when fungal spores are regularly carried by mites, as it concerns for example Ophiostoma sp. and some Tarsonemus species, the term hyperphoresy is commonly used (e.g. Wirth \& Pernek 2012). Fungus spores, which are carried by phoretic mites into bark beetle galleries can influence the microclimatic conditions inside these micro habitats (Wirth \& Pernek 2012). The authors of this research documented the case of Histiostoma sp. (Histiostomatidae), which was conspicuously covered by fungal spores of the Ascomycota.

It is important also for applied reasons to record phoretic mites on bark beetles as they can negatively influence the reproductivity of the beetles due to imported fungus spores or due to their life styles (e.g. Moser 1975).

Aim of this work was the recording of mite taxa being phoretically associated with Ips cembrae and Ips typographus Linnaeus, 1758 in Croatia. I. cembrae is a secondary pest of the European larch, Larix decidua Miller 1754 the species is also exceptionally able to colonize also spruce, Picea abies(L.) Karst Its impact is less harmful than the key pest I. typographus. These beetles are considered sister species by some authors (Stauffer, 1997)

\section{MATERAL AND METHODS MATERIJALI I METODE RADA}

\section{Locations of collections - Mjesta sakupljanja}

The sampling period was May 2012. Total numbers of collected mites are presented in Table 2. All sampling sites were located in Central Croatia and were characterized by a continental climate in the early summer season. Collectors were the authors themselves. Trees where the samplings were performed were usually still alive and characterized by yellow or reddish crones. All sampling areas were dense forests.

The key to determine juvenile stages of Histiostoma is based on studies performed at the Tyumen State University (Russia, 2015/ 16).

Sampling locations are shown in Fig. 1 with detailed description below:

- Nova Gradiška Ips typographus from Picea abies. $45^{\circ} 11^{\prime} 11^{\prime \prime} \mathrm{S}$,

$17^{\circ} 51^{\prime} 53^{\prime \prime} \mathrm{I}$

- Koprivnica Ips cembrae from Larix decidua. $46^{\circ} 08^{\prime} 13^{\prime \prime}$, $16^{\circ} 40^{\prime} 29^{\prime \prime} \mathrm{I}$

- Gospić Ips typographus from Picea abies and Pinus sylvestris. $44^{\circ} 50^{\prime} 04^{\prime \prime} \mathrm{S}, 15^{\circ} 14^{\prime} 49^{\prime \prime} \mathrm{I}$

- Jastrebarsko (Volavje) Ips typographus from five freshly felled tree trunks of Picea abies, stacked on each other for forestry utilization and being not yet decorticated, all beetle stages available in great numbers. $45^{\circ} 39^{\prime} 55^{\prime \prime} \mathrm{S}$, $156^{\circ} 36^{\prime} 04^{\prime \prime} \mathrm{I}$

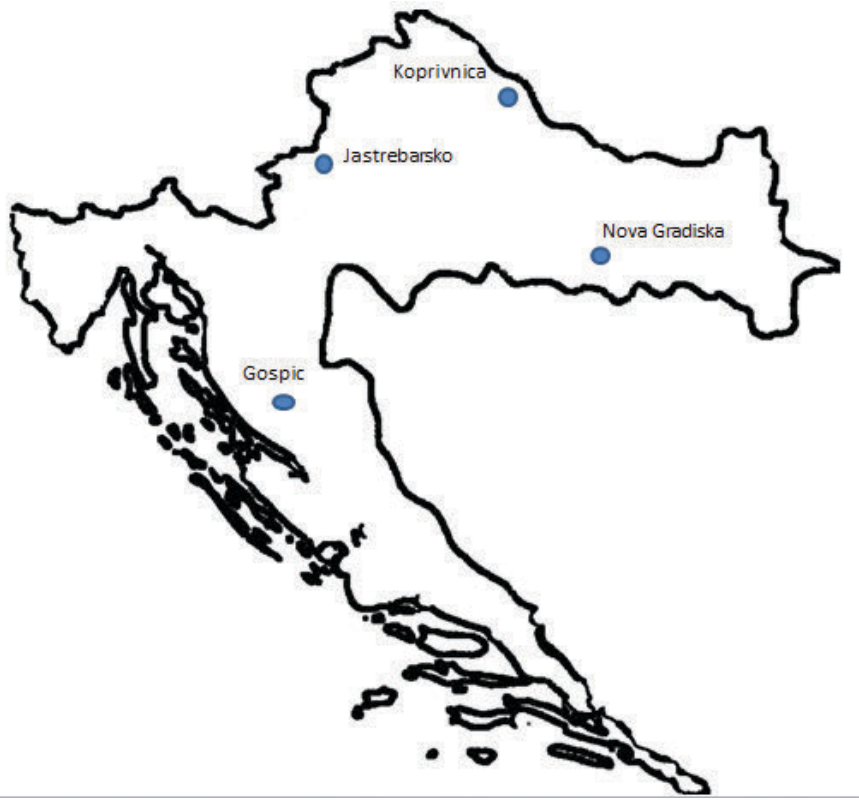

Figure 1: Shematic map of Croatia with sampling locations Slika 1: Shematska karta Hrvatske s lokacijama uzorkovanja

\section{Sampling - Sakupljanje uzoraka}

The bark of dead and still living trees was peeled of using a cleaver and a chisel. The collected pieces of bark with adult beetles, pupae and larvae were put into plastic bags (60 liters) for transport and to avoid dehydration. Additionally, single beetles and their larvae were individually collected out of their galleries, using a spring steel tweezer and were transferred into small plastic dishes (volumina $250 \mathrm{ml}$ and $125 \mathrm{ml}$ ). Original substrate (bark pieces and bore dust) was added.

At the sampling location Koprivnica, additionally to the usual sampling methods, three blocks were cut off a still living spruce tree trunk (height $40 \mathrm{~cm}, 50 \mathrm{~cm}$ in diameter). For this purpose, that almost dying tree was felled using a chainsaw and a cleaver. The blocks were finally cut off at a level between 3-5 m.

\section{Preparation of Samples - Priprema uzoraka}

Moist pulp paper was placed to the bottom of the dishes to guarantee permanent moisture. These dishes were used to keep beetles inside their original substrates alive. The same dishes were later used as cultivation wells for mites from these original substrates.

The wood blocks from Koprivnica were stored inside metal cages with a fine grid on all four sides to avoid an escape of newly hatched beetles. The cages remained in a climate chamber under controlled constant conditions $\left(21^{\circ} \mathrm{C}, 16 / 8\right.$ day-night-rhythm). The spruce blocks were sprinkled with water once every two days. In the same rhythm young beetles, which hatched out of the bark, were collected and examined for phoretic mites. Phoretic mite numbers on these young Ips cembrae beetles, which hatched out of the blocks and those from old beetles, which had been collected out of their galleries at the sampling site, were later compared with each other. Numbers 
of mites phoretically found on I. typographus were additionally statistically compared with mites which were discovered attached to I. cembrae.

\section{Evaluation of samples and mite cultivation - Evaluacija uzoraka i kultiviranje grinja}

Numbers of different phoretic mites on bark beetles were counted using a Zeiss-Stereo microscope. For this purpose, living beetles were carefully held with fingers or a spring tweezer, and mites, visible from outside, were counted. This procedure was practiced to secure that mites stay in their original positions. In contrast to that, dead beetles in alcohol usually lose most of their mites. But for this research, it was important to determine the different beetle areas of mite attachment. For this reason we divided the beetle body in Table 4 into head, thorax, Abdomen, coxae 1-3 and elytral declivity in order to define the mite's positions.

On a random basis, beetles in alcohol were observed (about 15 beetle specimens per species) for mites under their elytrae, where we didn't discover any mites. Additionally, living mites attached to beetles, which died under natural circumstances, were counted for comparisons. Beetles with and beetles without mites were kept in different dishes ( 15 dishes per beetle species with at least 3 beetle individuals inside). Dishes with beetles, which carried mites, were used as mite cultivation wells to imitate natural conditions as far as possible and to stimulate the development of histiostomatid mites. These cultivation wells were prepared as follows: beetles were put into Petri dishes (60 $\mathrm{mm}$ in diameter) and equipped with bark pieces with galleries and original bore dust. Raw potato pieces were added and sprinkled with some water in a two-day rhythm to stimulate the growth of bacteria, which usually represent the food source for mites of the Histiostomatidae. The closed Petri dishes $(60 \mathrm{~mm} \varnothing)$ and small plastic dishes $(250 \mathrm{ml}$ and $125 \mathrm{ml})$ were kept at room temperature $\left(\mathrm{ca} .20^{\circ} \mathrm{C}\right)$. Sufficient moisture (that potatoes were partly covered by a thin layer of „slime”) was guaranteed not only by a moist layer of pulp paper, but also due to the fact that both types of dishes were covered by plastic containers. Adults and free living instars besides the phoretic deutonymph need to be available for a useful determination of the species. Iponemus gaebleri Schaarschmidt, 1959 (Tarsenomidae) could develop inside the same dishes, in which histiostomatid mites were reared.

\section{Key to larvae and protonymphs within the genus Histiostoma - Ključ za larve i protonimfe unutar roda Histiostoma}

Histiostomatid mites develop often synchronously, thus in young colonies, adults and deutonymphs might be missing. This herewith introduced original key shall enable the identification of histiostomatid mites by their larvae and protonymphs. Tritonymphs are not included as their morphology appears to be variable throughout genera and species.

Many species and genera of the Histiostomatidae are based on the deutonymph morphology, only occasionally also adults were described. The whole set of developmental stages appears only rarely in species descriptions. Such descriptions and species studied by this author contributed to this key. It is based on phylogenetic comparative morphological comparisons concerning nymphal characters, which are named in the key. These characters were mapped on the phylogenetic tree of Wirth (2004). The following key of larvae and protonymphs is based on species of the following genera and species: Aphodanoetus, Bonomoia, Glyphanoetus, Myianoetus, Sarraceniopus, Histiostoma brevimanus Oudemans 1914, $H$. julorum Koch 1843, $H$. feroniarum Dufour 1839, H. sp. (ex sap flux Berlin, Germany), H. ovalis Müller 1860, H. piceae Scheucher 1957, H. sp. (ex rotting tree stump Saarland, Germany), H. sp. (ex rotting wood Vladivostok/ Russia).

Non-Histiostoma outgroup Astigmata were mites of the genera Acarus, Sancassania and Rhizoglyphus.

\section{Statistical evaluation - Statistička obrada}

The statistical evaluation of mite numbers attached to beetles and their preferred areas on these beetles was made using the software SPSS 15.0 for Windows (SPSS Inc. Released 2007. SPSS for Windows, Version 16.0. Chicago, SPSS Inc.).

Mite numbers on different beetles were compared with each other using the Kolmogorov-Smirnov test and the Shapiro Wilk test to determine whether or not a random sample of values follows a normal distribution. Using these tests we evaluated numbers of mites per beetles in terms of the data sets „Ips typographus (total) “ and „Ips cembrae (total)“.

Using the Mann-Whitney Rank-Sum test for independant samples we compared the groups of beetles in regard of their numbers of phoretic mites.

\section{RESULTS}

\section{REZULTATI}

1) Collected mite species and their preferred body regions of the beetles

Table 1: Ips typographus - samples from Jastrebarsko

Tablica 1: Ips typographus - uzorci iz Jastrebarskog

\section{Tree 1 Numerous freshly hatched beetles, pupae and larvae}

Tree 2 Numerous cadavers of larvae and pupae

Tree 3 Numerous adult beetles (parental beetles)

Tree 4 Single adults (parental beetles) and numerous freshly hatched beetles Tree 5 Adults (parental beetles) and eggs

Mites phoretically attached to Ips typographus or found inside its galleries: Beetle specimens (parental beetles) for this evaluation were collected in nova Gradiska and Gospic. The most abundant mite was Iponemus gaebleri (Tarsenomidae, Fig. 5 C). The uropodid Urobovella sp. (Fig. 6 C) appeared once as a deutonymph on a beetle specimen. Dendrolaelaps quadrisetus (Fig. 6 B) and Histiostoma piceae (Fig. 5 D, E, F) could not be found atttached to any beetles, but appeared regularly as free living stages inside the gallery-samples. 
Table 2: Overview - descriptive statistics

Tablica 2: Pregled deskriptivne statistike

\begin{tabular}{|c|c|c|c|c|}
\hline & Ips typographus (in total) & Ips cembrae (in total*) & Ips cembrae (galleries) & $\begin{array}{l}\text { Ips cembrae (flown out } \\
\text { young beetles) }\end{array}$ \\
\hline $\mathrm{N}$ beetles & $\begin{array}{c}76 \\
\text { (N: 34, G: } 5, \mathrm{~J}: 37)\end{array}$ & 171 & 100 & 71 \\
\hline Beetles with mites in $\%$ & $\begin{array}{c}30,26 \\
\text { (N: 56, G: 40; J: 5) }\end{array}$ & 66,66 & 48 & 92,96 \\
\hline Mites (in total) & $\begin{array}{c}416 \\
\text { (N: 395, G: 7, J: 14) }\end{array}$ & 4533 & 567 & 3966 \\
\hline
\end{tabular}

$\mathrm{N}=$ Nova Gradiska, $\mathrm{G}=$ Gospic, $\mathrm{J}=$ Jastrebarsko; numbers of evaluated beetles and of all mite specimens(representatives of different mite groups)

Table 3: Distribution of mite species on beetles in percent

Tablica 3: Postotna distribucija grinja na potkornjacima

$\begin{array}{lcccc} & \begin{array}{c}\text { Ips cembrae from } \\ \text { substrate }\end{array} & \begin{array}{c}\text { Ips cembrae Emerged } \\ \text { Young beetles }\end{array} & \begin{array}{l}\text { Ips cembrae (in total) } \\ \text { Ips tyographus }\end{array} & 99.8 \\ \text { Iponemus gaebleri } & 96 & 98.8 & 97.4 & - \\ \text { Gamasina: Dendrolaelaps } & 3.7 & 0.43 & 2.1 & - \\ \text { quadrisetus } & - & 0.73 & 0.37 & 0.2 \\ \text { Histiostoma sp. } & & & & \end{array}$

Inside the galleries additionally Histiostoma sp. (Histiostomatidae, Fig. 6 E) and two oribatid speciemens of the genus $\mathrm{Ne}$ oliodes sp. (Fig. $6 \mathrm{D}$ ) could be collected. Neolides sp. was more exactly collected from an area, in which smaller bark beetles of Pityogenes sp. had connected their tiny gallery system with the one of I. typographus.

Being attached to Ips cembrae the tarsenomid mite Iponemus gaebleri was statisticallly significantly most abundant in relation to the gamasid species Dendrolaelaps quadrisetus and the astigmatid species Histiostoma piceae.

Over $90 \%$ of the beetle specimens, which had left the wooden blocks inside the climate room, were covered with I. gaebleri and deutonymphs of H.piceae (table 2).

Inside the galleries of I. cembrae, some single males of Bonomoia pini (Histiostomatidae) were discovered.

2) Distribution of phoretic mites on I. typographus and I. cembrae

In both beetle species, I. typographus and I. cembrae, the significantly greatest number of I. gaebleri individuals was located inside the elytral declivity (Table 4, Fig. 2, Fig. 3) posteriorly of the abdomen. In I. typographus 412 out of 416 Iponemus gaebleri specimens were found inside the elytral declivity, while in Ips cembrae 4140 von 4465 attached this area of the beetle body. The phoretic deutonymphs of Histiostoma piceae however only rarely preferred this declivity, but principally were instead sitting around the ventral thorax. H. piceae was only found phoretically attached to I. cembrae. Despite its abundance inside the galleries of I. typographus, their deutonymphs could not be descovered on these beetles themselves.

The uropodid mite Urobovella sp. was only a single discovery (Fig.6, table 3). Thus there is also no meaningful result concerning the preferred position on the beetle's body.

The significantly greatest number of I. gaebleri individuals preferred the elytral declivities in both bark beetle species. Also the gamasid D. quadrisetus was significantly most often found in these areas of I. cembrae. It was observed that the gamasid did not avoid specimens of I. gaebleri sitting in the same area oft the beetle's body. Instead they were found attaching themselves on top of the tarsenomid mites specimens, which were

Table 4: Distribution of mites on the different beetle samples, in percentage

Tablica 4: Postotni raspored grinja u različitim uzorcima potkornjaka

\begin{tabular}{|c|c|c|c|c|c|c|}
\hline & $\begin{array}{c}\text { Ips cembrae } \\
\text { (galleries) } \\
\text { Iponemus gaebleri }\end{array}$ & $\begin{array}{c}\text { Ips cembrae } \\
\text { (flown out) } \\
\text { Iponemus gaebleri }\end{array}$ & $\begin{array}{l}\text { Ips typographus } \\
\text { Iponemus } \\
\text { gaebleri }\end{array}$ & $\begin{array}{l}\text { Ips cembrae } \\
\text { (galleries) } \\
\text { Gamasina }\end{array}$ & $\begin{array}{l}\text { Ips cembrae } \\
\text { (flown out) } \\
\text { Gamasina }\end{array}$ & $\begin{array}{l}\text { Ips cembrae } \\
\text { (flown out) } \\
\text { Histiostoma }\end{array}$ \\
\hline Coxae & - & 0.05 & - & - & - & - \\
\hline Legs & - & 0.02 & - & - & - & - \\
\hline Head (in total) & - & 0.15 & - & 4.5 & - & - \\
\hline Thorax (in total) & 1.8 & 1.95 & 0.48 & - & 5.88 & 89.65 \\
\hline Abdomen (in total) & 3.8 & 5.32 & 0.48 & 9 & 29.41 & 6.9 \\
\hline Declivity & 94.2 & 92.45 & 99 & 86 & 64.7 & 3.45 \\
\hline Relation dorsal to ventral (in total) & $97.78 / 2.02$ & $97.65 / 2.35$ & $99.75 / 0.25$ & $95.45 / 4.55$ & $100 / 0$ & $6.9 / 93.1$ \\
\hline
\end{tabular}



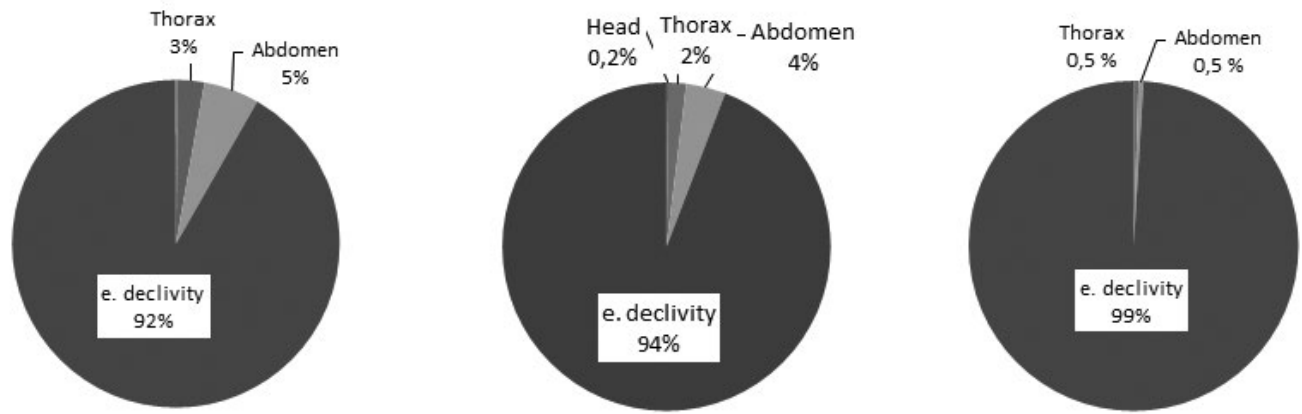

Figure 2: distribution of phoretic mite species on the beetles of Ips typographus and I. cembrae Dark gray: elytral declivity, medium gray: thorax, light gray: abdomen,.

Slika 2: distribucija foretičkih grinja na potkornjaku Ips typographus i I. cembrae. Tamn osiva: obronak zadka, srednje sivo: prsište, svijetlo siva: abdomen

sitting attached to the beetle's cuticle one directly besides the other. The arrangement of I. gaebleri specimens reminded to roofing tiles. While I. gaebleri attached themselves in close contact to the carrier's surface, Dendrolaelaps retained in a loose contact to its base consisting of I. gaebleri specimens. The gamasids did not rest in the same positions, but were observed changing their places regularly. Histiostoma piceae however preferred attaching thorax and abdomen in significantly great numbers. In these areas they were found sitting dorsally as well as different ventral areas. In our statistical analysis, we summarized histiostomatid numbers on ventral and dorsal body parts, although ventral areas seemed slightly to be favored. But due to not enough numbers, we did not try to analyse this by statistical tests (table 4).

When summarizing all mite numbers on both types of samples of I cembrae, then there is no significant difference visible. Parent beetles inside their new galleries have as much phoretic mites as young beetles, which had recently left the galleries, in which they had developed. In both groups of samples, about $92 \%$ of all mites preferred attaching the elytral declivity (Fig. 2 ). The preference for this beetle area as field of mite attachment is even clearer visible in the samples of I. typographus, where almost 100 percent of mites were found inside the declivity (Fig. 2).

When summarizing the two types of I. cembrae samples into one set of data, but differing the mite taxa from each other, then it became visible that Iponemus gaebleri and Dendrolaelaps quadrisetus significantly preferred attaching to the elytral declivity, while Histiostoma piceae could significantly most often been found sitting on the thorax area (Fig. 3).

We furthermore compared the numbers of specimens of the different mite groups per samples of beetle groups, and it became obvious that in all three beetle samples Iponemus gaebleri was statistically most abundant (Fig. 4). Only in the samples with mother beetles collected out of their galleries, the mite Dendrolaelaps quadrisetus (Gamasina) was with $3.7 \%$ versus 96.1 (I. gaebleri) statistically noticeable (Fig. 4).

3) numbers of mites of three taxa in comparison with each other

When summarizing the two types of I. cembrae samples, it came out that neither the sample „I. cembrae total“ nor the sample „I. typographus“ had a normal distribution of mites.
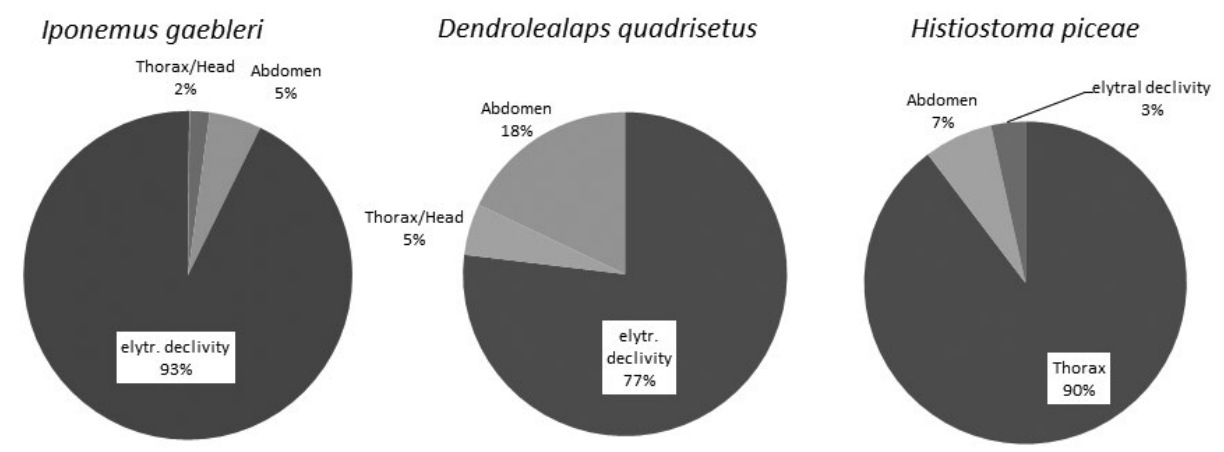

Figure 3: Distribution of Iponemus gaebleri, Dendrolaelaps quadrisetus and Histiostoma piceae on beetles of Ips cembrae (both sample types summarized), dorsal and ventral positions were summarized, dark gray: elytral declivity, medium gray: thorax/head, light gray: abdomen.

Slika 3: Distribucija Iponemus gaebleri, Dendrolaelaps quadrisetus and Histiostoma piceae na potkornajcima Ips cembrae. Tamno siva: obronak zadka, srednje sivo: prsište/glava, svijetlo siva: abdomen 

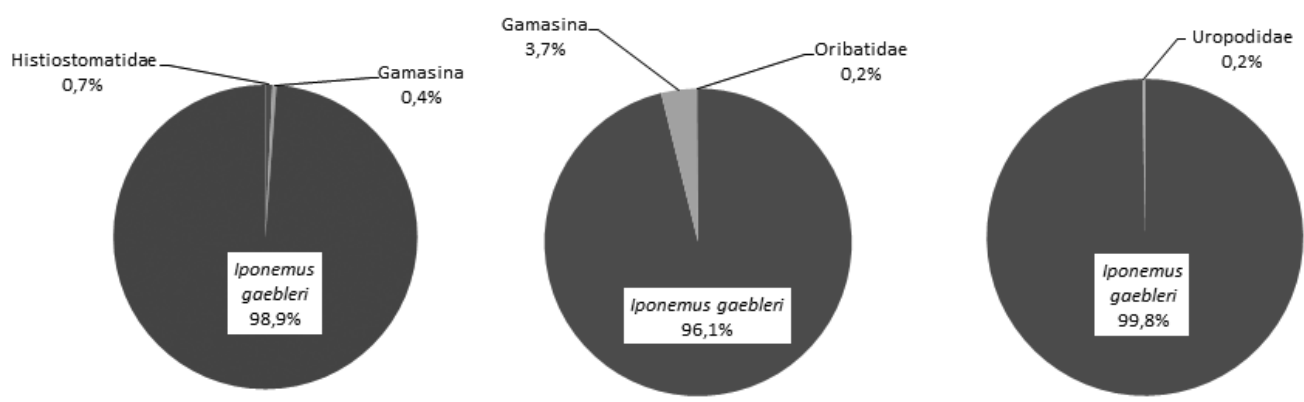

Figure 4: Numbers of mites per examined beetle group: Ips cembrae and Ips typographus were compared with each other. Gray: Iponemus gaebleri, dark gray: Dendrolaelaps quadrisetus (Gamasina), light gray: Histiostoma piceae/ Oribatidae/ Urobovella sp. (Uropodidae)

Slika 4: Usporedba broja grinja po pregledanim kukcima: Ips cembrae i /ps typographus. Sivo: Iponemus gaebleri, tamno sivo: Dendrolaelaps quadrisetus (Gamasina), svijetlo sivo: Histiostoma piceae/ Oribatidae/ Urobovella sp. (Uropodidae)

Iponemus gaebleri, Dendrolaelaps quadrisetus and Histiostoma piceae:

Using the Mannn-Whitney U-Test it could be shown that Iponemus gaebleri specimens per beetles of I. cembrae (both sample types summarized) are statistically significantly higher than numbers of the same mite per beetles of I. typographus. Summarizing the two sample types of I. cembrae (beetle mothers in their galleries and flown out young beetles) for a comparison with I. typographus was appropriate, because numbers of I. gaebleri mites on these two types of I. cembrae samples were found being statistically equal.

Dendrolaelaps quadrisetus was only found on the two types of I. cembrae beetle samples. There was no significant difference between numbers of $D$. quadrisetus on parental beetles collected out of their galleries and young emerged beetles from the wood blocks stored in the climate chamber.

Histiostoma piceae deutonymphs could only be discovered on one of the two Ips cembrae samples (emerged young beetles). Thus comparisons with other beetle samples were not workable.

4) Qualitative observations on mites attached to Ips typographus from Jastrebarsko

The Ips typographus-samples from Nova Gradiska, Gospic und Jastrebarsko were concluded for our statistical analysis. But the samples, collected in Jastrebarsko, enabled additionally some qualitative findings. There numerous felled tree trunks of $P i$ cea abies layed besides each other and contained different developmental stages of the beetle close each other (Table 1).

None of the larvae of I. typographus carried any phoretic mites. Also freshly hatched young beetles were free of mites. These beetles were unequivocally recognized as freshly hatched due to their still not yet sclerotized cuticles. Iponemus gaebleri as representant of the Tarsenomidae appeared, contrary to findings in our other collecting areas, unusually rarely. Only 2 out of 37 (23 older adult beetles, presumably parental beetles, 14 freshly hatched individuals and 20 larvae) beetles carried $I$. gaebleri individuals (table 1). Representatives of other mite groups were not found attached to the older parental beetles. Instead, specimens of Histiostoma piceae appeared inside the galleries in different developmental stages. Also I. gaebleri specimens had colonized that substrate. There were not enough data available for a statistical evaluation.

5) Mite developmental stages inside the bark samples with galleries of I. typographus and I. cembrae

5.1.) preferred areas of mite instars inside the bark beetle galleries

Iponemus gaebleri specimens were often discovered in greater numbers in bark pieces with I. typographus galleries (Fig. $5 \mathrm{~A}$, B, G), up to 100 specimens in about 20 out of about 80 cases. Adults and quiescent young adults still in their larvae's cuticles appeared in greater aggregations on decomposed dead bodies of I. typographus. These cadavers represented either freshly hatched young beetles or still pupae. Both had retained inside their pupa chambers. There, groups of 18-20 quiescent mite adults in larva-exuviae could sometimes be found (Fig. 5 B). Adults were crawling around in smaller numbers. Mold growth partly covered the areas around those chambers.

Histiostoma sp. was typically discovered in the same areas (Fig. $6 \mathrm{E}$ ). Only adult females could be found there. The species is characterized by a dorsal setation reminding to mites of the Genus Glyphanoetus. It is unknown, whether $H$. sp. reproduces thelytokously or whether males are only rare and were overlooked. Their preferred habitats were slightly moist, rich of bacteria and fungal hyphes (mostly mold fungae). It was not directly observed, which food this histiostomatid preferred. Almost one hundred percent of these mite specimens were remarkable covered by fungus spores (see next chapter).

Histiostoma piceae could be reared in greater numbers in the original bark substrate of both beetles, I. typographus and I. cembrae. It was observed that most specimens preferred the areas close to their beetle carriers, which were additionally kept 
inside their substrates. But with increasing numbers of mites after about two weeks, mites began to develop in all kinds of areas, as far as the habitats were not too dry or too moist. They preferred a substrate being covered by a thin slimy film of moisture.

The gamasid mite Dendrolaelaps quadrisetus was observed being often actively walking around areas, where Histiostoma piceae specimens appeared in greater numbers. The same areas were also colonized by free living nematodes. It is not known, whether D. quadrisetus was feeding on histiostomatids, nematods, both of them or more likely on other organisms.

\section{2.) fungus spores attached to Histiostoma sp.}

Histiostoma sp. was observed being remarkably covered by substrate particles, different smaller fungal spores, but especially by conspicuous two-chambered spores (Fig. $6 \mathrm{E}$ ). They belong to an undetermined species of Ascomycota (Hypocreales). Single females of $H$. sp. carried 100 or more of these spores over their whole bodies. They especially were sticking in greater numbers to the dorsal area of the gnathosoma, to legs I and II and to the distinctly elongated setae of the hysterostoma.

The spores attached to the mite body due to the sticky cuticle, which is typical for astigmatid mites. Oil gland components are responsible for this effect (i.a. Koller et al. 2012). The spores additionally were sticking against each other due to an unknown mechanism. Also the confusing arranged dorsal setation of the mites allowed the mechanical holding of these spores and all other visible particles.

Mites were not visibly harmed by these objects, which they were carrying on their backs. They were motile and showed a healthy histiostomatid behavior.

6.) key to free living stages of Histiostoma bark beetle-group

The nomenclature of dorsal setae in larvae and protonymphs fellows Griffiths et al. (1990).

larva (histiostomatidae/ Astigmata):

1. mouthparts modified: digitus mobilis reduced to remnants, distal pedipalp article bulged sidewards, membraneous structures at distal pedipalps ---- 3 .

2. mouthparts in the typical arachnid shape ---- 4 .

3. larvae of the Histiostomatidae ---- 5.

4. larvae of other Astigmata groups

5. the following dorsal setae arranged on separate distinctly sclerotized cuticular plates: median plates containing a pair of setae: setae $\mathrm{d} 1$ and setae el; single plates on each side for $\mathrm{c} 2$ and h2 ---- Histiostomatidae cp on a rounded cuticular shield ---- Genus Histiostoma $---6$.

$\mathrm{cp}$ on indistinct elevation or completely without cuticular shield ---- other Genera of Histiostomatidae

6. setae $c 3, \mathrm{c} 2$ and $\mathrm{cl}$ on a common cuticular plate on each side --- bark beetle clade within genus Histiostoma (Fig. $7 \mathrm{~B})$ protonymph (Histiostomatidae/ Astigmata)

1. mouthparts modified: digitus mobilis reduced to remnants, distal pedipalp article bulged sidewards, membraneous structures at distal pedipalps ---- 3 .

2. mouthparts in the typical arachnid shape ---- 4 .

3. protonymphs of the Histiostomatidae ---- 5.

4. protonymphs of other Astigmata groups

5. setae $\mathrm{f} 2$ and oilgland opening on each side arranged on a common cuticular plate, which can also be a partly sclerotized area, thus forming no complete rounded shield---- Histiostomatidae, different genera

setae $\mathrm{d} 1$ and el on two median cuticular shields containing setae of both sides --- bark beetle clade within genus Histiostoma (Fig. 7 A)

\section{DISCUSSION \\ RASPRAVA}

Comparisons between numbers and positions of phoretic mites on the beetles I. typographus and I. cembrae from Croatia were never performed before. Our analysis in this context was based on qualitative information as we had decided not to use traps, but to collect all beetles available for our evaluations alive. Thus we ensured that phoretic mites remained on their beetles in their orginal positions.

An interesting finding concerned comparisons between young beetles, emerged from their juvenile galleries, with older parental beetles. Numbers of attached mites on these beetle groups were statistically similar. Samplings on a random basis of larvae, pupae and freshly hatched beetles of I. cembrae had no phoretic mites. This was confirmed by a qualitative study on the closely related I. typographus (galleries collected in Jastrebarsko). According to these findings phoretic mites, in this case I. gaebleri and H. piceae, do not secure their carriers in the pupa stage or shortly after their hatching, but anytime subsequently. There is no indication about the detailed circumstances, in which I. gaebleri males get on their carriers. But deutonymphs of $H$. piceae might ascend their beetles in the areas of their exit holes. This assumption is supported by observations, which Wirth (oral communication) made in older studies on a related mite species from bark beetle galleries of an undetermined and absent beetle in Louisiana (USA). Deutonymphs here had conspicuously aggregated around the numerous exit holes.

Although especially Histiostoma piceae seemed to prefer areas close to living beetles for their development, they did not develop on or around beetle cadavers. This is confirmed by our findings, whereby both mite species, I. gaebleri and H. piceae, remained for a longer while on died beetles, but then left these cadavers consecutively. The strategy of necromeny (Wirth, 2009) is obviously not even practised as a byway by both mite species.

The finding that mites stay for days on the cadavers of their carriers indicates that the stimulus to leave depends much 
more on a suitable habitat around than on the vitality of the beetles. Larvae of I. gaebleri nevertheless seemed to have an affinity to the cadavers of beetle larvae or pupae (Fig. 5 A, B, $\mathrm{G})$. But this is discussed further below.

Both bark beetle species, Ips cembrae and I. typographus, were mostly associated with the same species of phoretic mites. Not all of them were originally described as being associated with different carriers. Scheucher (1957) had described Histiostoma piceae as being strictly specific on I. typographus only. But several authors discovered $H$. piceae also on other beetle carriers, as e.g. Pernek et al. (2008, 2012), who found deutonymphs attached to Pityokteines curvidens Germar, 1824 In order to verify, whether $H$. piceae was correctly determined on I. cembrae and I. typographus, we reared the isolated mites. Adults and deutonymphs from both beetles were identical to the description of Scheucher (1957). Thus we could confirm that $H$. piceae is not specifically associated with $I$. typographus, but at least in Central Croatia also with I. cembrae. Due to the lack of comparative studies on other bark beetle species based on all developmental mite instars, we don't know, whether this mite is restricted to those two bark beetle species, representing sibling species to each other, or whether $H$. piceae has a wider range of phoretic carriers. The correct determinations of $H$. piceae on other bark beetle species, based on the deutonymph only, need to be verified in the future.

The undetermined species Histiostoma sp., which was only available as adult females in the galleries of $I$. typographus, is assumed being adapted for carrying soil particles as tactile camouflage as common in the Histiostoma-bark-beetle-clade (Wirth, 2004). As there were no limitations in the behaviors of the observed specimens visible, the numerous fungus spores, which covered their whole bodies, were not interpreted as artefacts, but as an intended phenomenon. Being covered with substrate, which can also consist of fungus spores, might impede the tactile detection by predators. It is not known, whether this mite specifically carries spores only or whether it would cover its body with all kind of available soil. The specimens of these studies carried additionally to the two-chambered spores also the spores of different other fungal groups together with soil particles. This might support the theory that dorsal structures could function as substrate holders „on purpose“.

Although the spores were discovered attaching on different body parts, the conspicuous dorsal setation seems mainly to support the holding of particles. The fungus might benefit from these mites due to a dispersal of its spores.

Generally, different instars of histiostomatids from the bark beetle group were repeatedly observed carrying fungal spores, at least in a lower number, e.g. found on specimens of Histiostoma ovalis (Wirth \& Garonna, 2015).

Scheucher (1957) assumed that very different arthropods might act as carriers for Bonomoia pini, such as chilopods, tenebrionids or coccinelids. On the other hand she stated that all these putative carriers need to visit galleries of the bark beetle Hylastes ater regularly as she only inside those galleries had discovered the stages of $B$. pini including the deutonymphs, which according to her findings hibernate under the bark. In case we correctly determined $B$. pini based on male specimens in our study about I. typographus and I. cembrae, our findings indicate a wider range of phoretic bark beetle carriers than assumed by Scheucher (1957). Based on the deutonymph, $B$. pini was already repeatedly discovered on numerous bark beetle species before. Penttinen et. al (2013) for example name $I$. typographus as a phoretic carrier. B. pini thus seems not being specific to galleries of $H$. ater only, but prefers at least different bark species of Curculionidae. Whether even other arthropods can carry this mite, up to date remains an unproven speculation of Scheucher (1957).

The tarsonemid mite I. gaebleri (Fig. 5 C) was already known to be carried by different bark beetle species and was here undoubtfully determined by W. Magowski. It was for example known being associated with Ips borealis and I. pilifrons (Boss et al. 1970). But also the phoretic association with I. typographus was documented in Moser et al (1989). A statistical comparison of I. gaebleri individuals between two different phoretic beetle carriers in Croatia were never performed before. The results show that there was no equipartition between mite numbers on I. typographus and I. cembrae. Our studies showed a significant higher number of mite specimens on I. cembrae. This result might be due to unknown ecological preferences of the mites. A putative argument for the missing equipartition could be the slightly bigger size of I. cembrae in relation to $I$ typographus.

Dendrolaelaps quadrisetus (Fig. $6 \mathrm{~B}$ ) is a common phoretic guest on different bark beetle species. According to Moser (1995), it appears in a large number of habitats and on a large number of „insect host species“. Mites of the genus Dendrolaelaps feed as predators on smaller organisms, often on nematodes (Kinn, 1984). We assume that D. quadrisetus might be a predator of juvenile histiostomatids.

The very low abundance of Urobovella sp. (Fig. 6 C) on beetles is not clearly explainable, but might be a consequence of competition between different phoretic mite groups on a beetle. Especially the very high numbers of Iponemus gaebleri specimens might act as a limitating factor for uropodids, which thus putatively were prevented to detect a suitable area for a stable attachment.

Our findings about the preferred positions of phoretic mites on their carrier beetles indicate that attachment places were not occupied accidentally. Obviously the competition between different mite groups resulted in occupying different areas on a beetle. Preferences of phoretic mites for specific areas on their carriers were for example described for Histiostoma ovalis on Ips sexdentatus (Wirth \& Garonna, 2015). According to the cited paper, also movements of the beetle might influence the final positions of mites.

Our most important findings of specific interest for the forestry research was the very high abundance of I. gaebleri, whose females use to feed on bark beetle eggs (oral commu- 


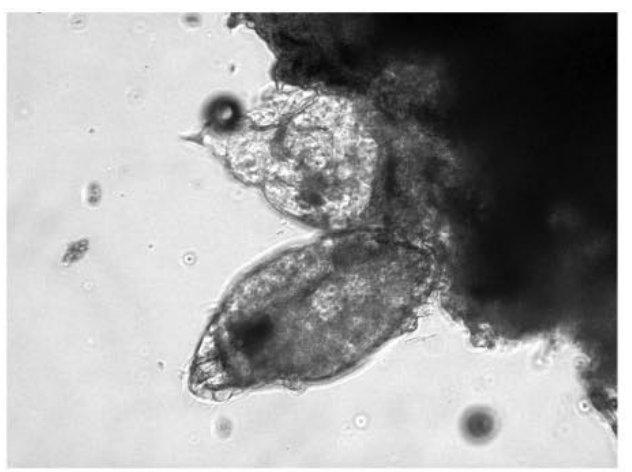

A B
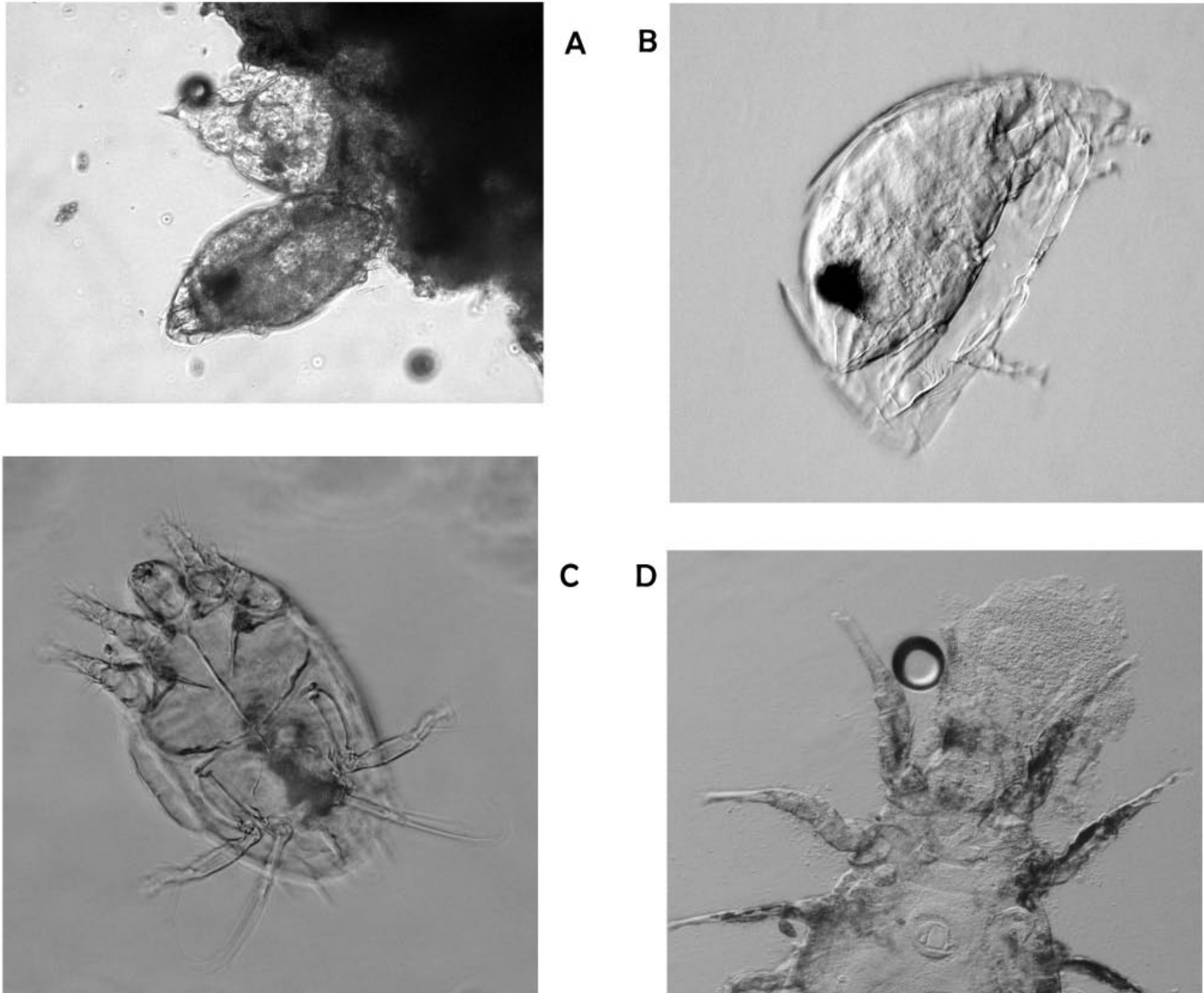

C D
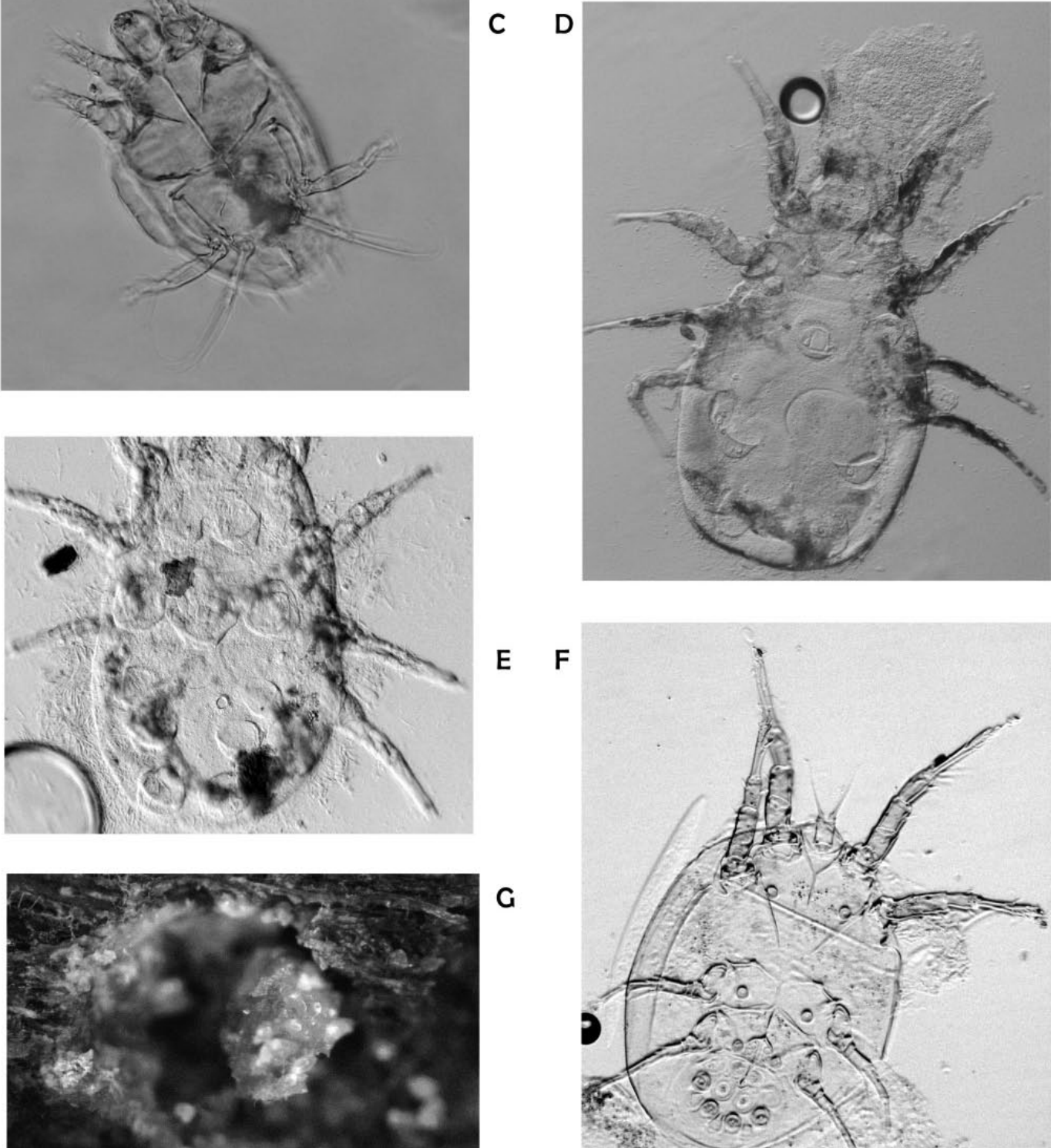

G

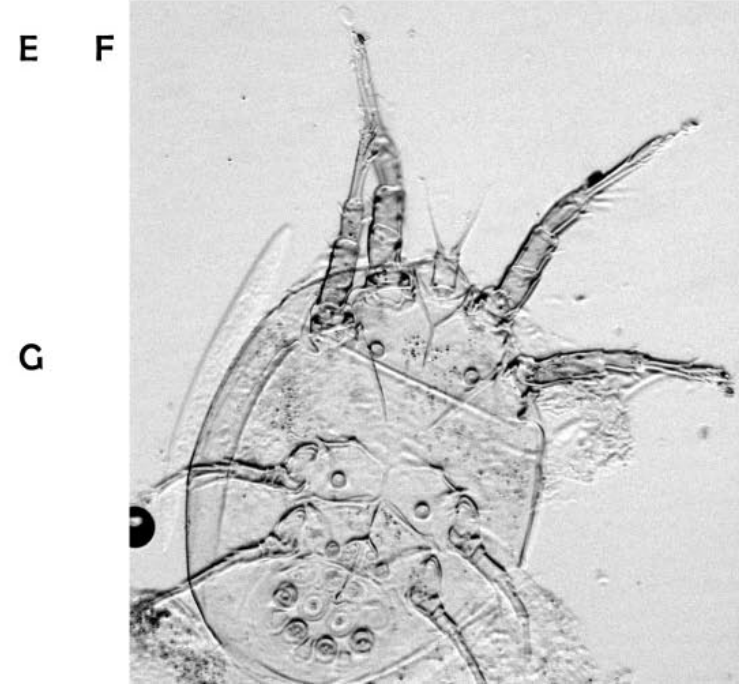

Figure 5: Mites from Ips typographus and I. cembrae. A: adults of Iponemus gaebleri still in their larvae cuticles attached to the remnants of a beetle pupa or larva cadaver (galleries of I. typographus); B: I. gaebleri inside the larva cuticle in higher magnification; C: adult female of I. gaebleri in ventral view; D: adult female of Histiostoma piceae in dorsal view; E: protonymph of $H$. piceae in dorsal view; F: deutonymph of $H$. piceae in ventral view; G: stereomicroscopic magnification of young I. gaebleri adults inside their larvae cuticles, attached to remnants of a beetle pupa or larva cadaver inside a pupa chamber.

Slika 5: grinje nađene na Ips typographus and I. cembrae. A: adulti Iponemus gaebleri u larvalnoj ovojnici spojena sa ostatkomkukuljice ili kadavera (galerije I. typographus); B: I. gaebleri unutar larvalne ovojnice; C: adult ženke I. gaebleri ventralno; D: adult ženke Histiostoma piceae dorzalno; E: protonimfa H. piceae dorzalno; F: deutonimfa H. piceae ventralno; G: mladi adult I. gaebleri u larvalnoj ovojnici, spojena s ostatkomkukuljice ili kadavera. 


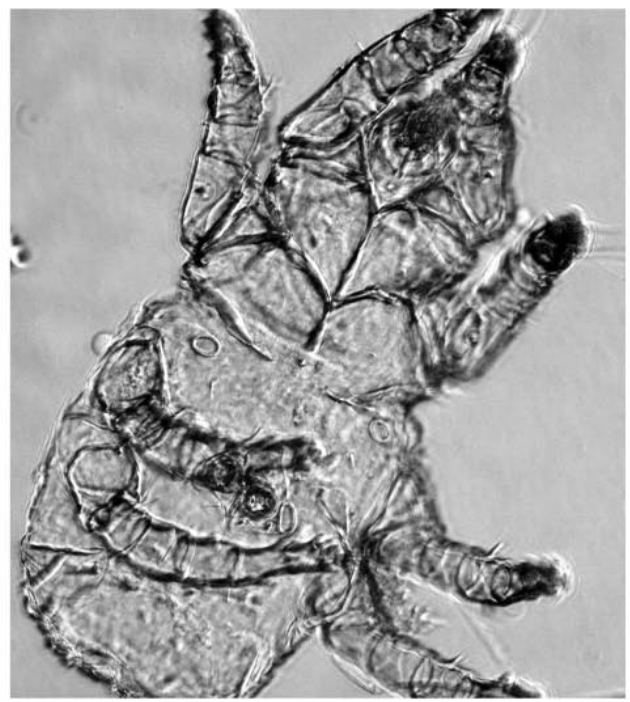

A
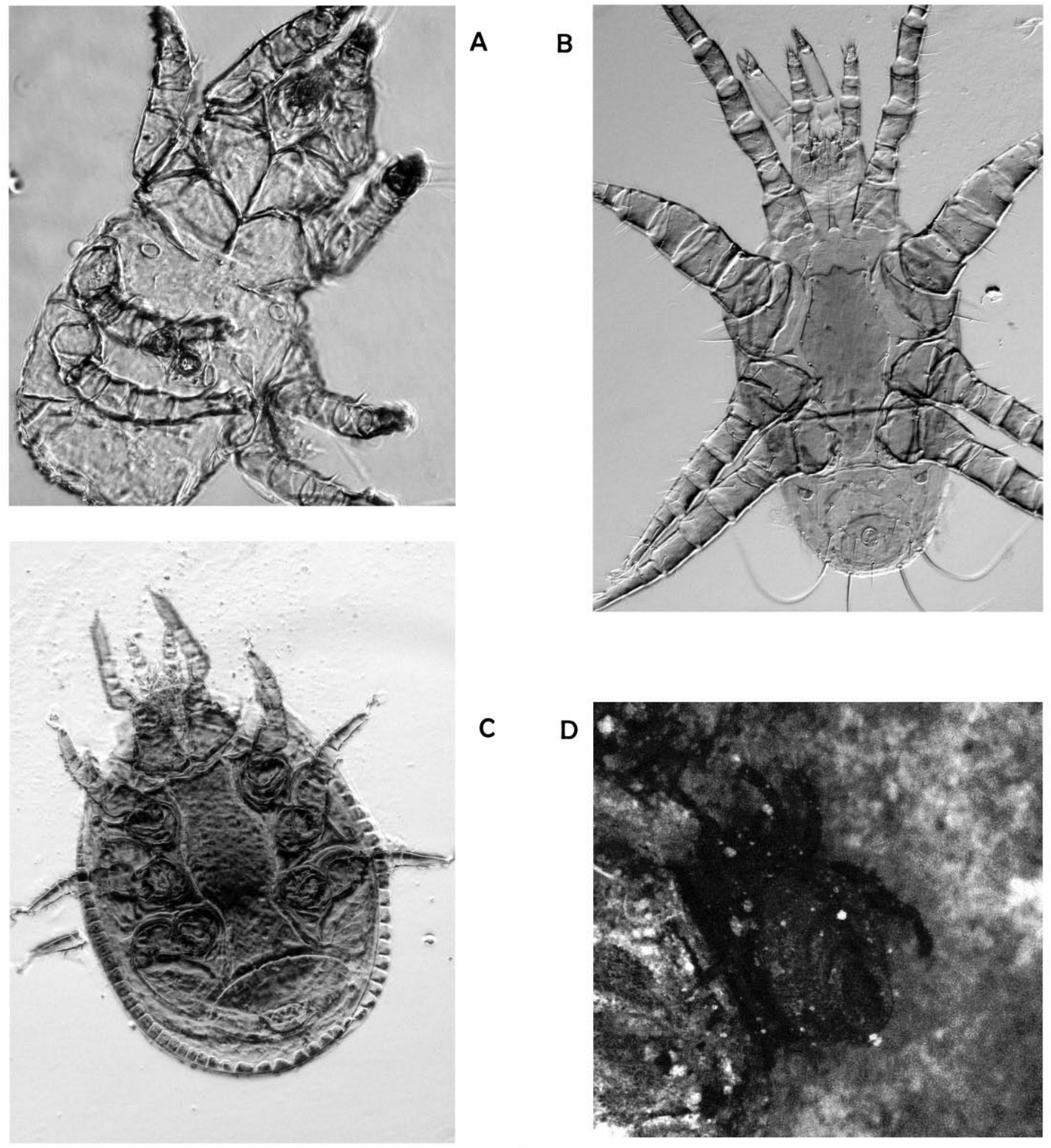

C

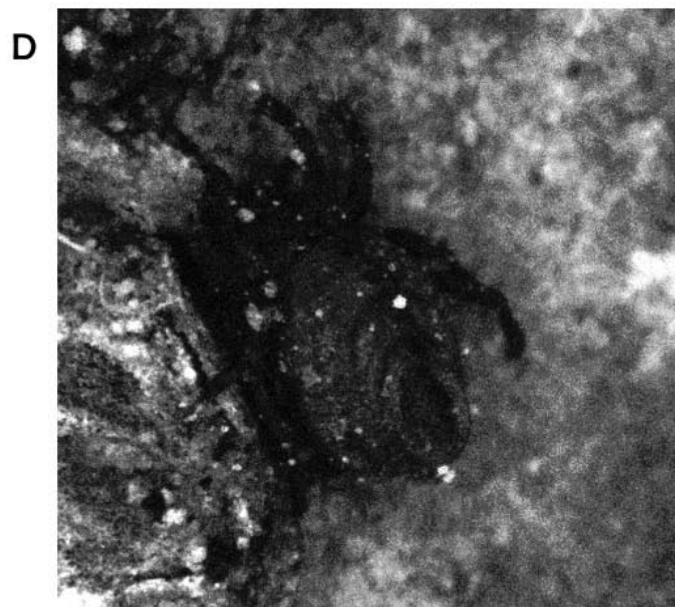

E

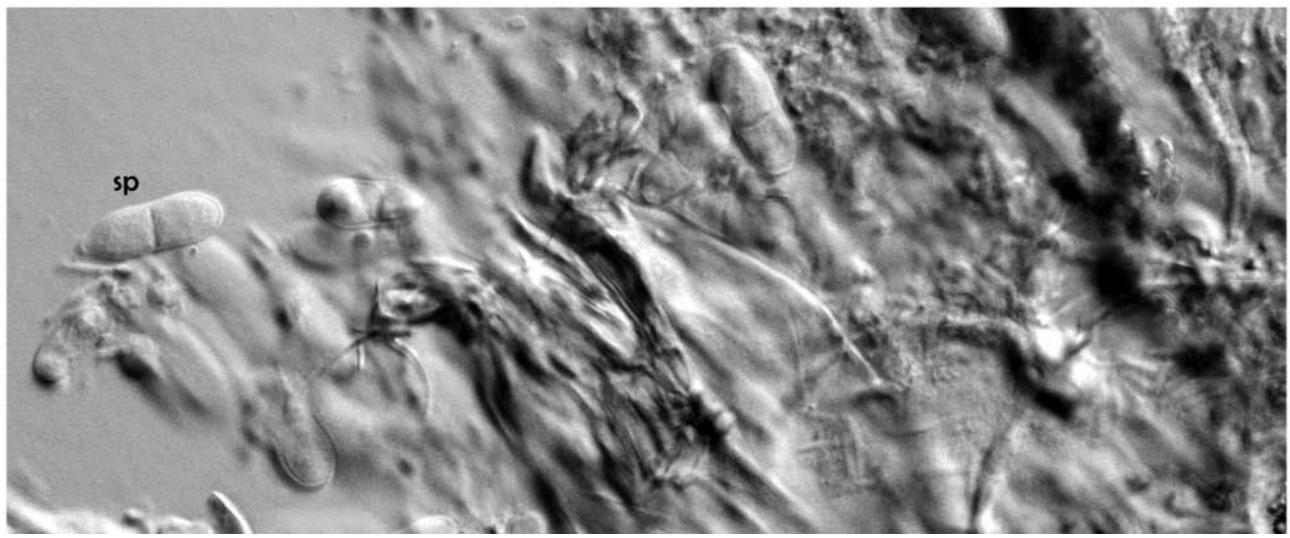

Figure 6: Mites from galleries or directly the beetles of Ips typographus and I. cembrae. A: male of Bonomoia pini in ventral view out of the galleries of I. cembrae; B. Dendrolaelaps quadrisetus in ventral view; C: Urobovella sp. in ventral view from a beetle of I. typographus; D: Neoliodes $\mathrm{sp}$. in dorsal view inside the galleries of I. typographus galleries (stereomicroscopic magnification); E: Histiostoma sp. with two chambered fungus spores from galleries of $I$. typographus (dorsal view on the gnathosoma)

Slika 6: Grinje s potkornjaka ili hodnika Ips typographus i l. cembrae. A: mužjak Bonomoia pini ventralno nađen u hodnicima I. cembrae; B. Dendrolaelaps quadrisetus ventralno; C: Urobovella sp. ventralno s tijela kukca I. typographus; D: Neoliodes sp. Dorzalno; unutar hodnika I. typographus galleries; E: Histiostoma sp. Sa dvije spore iz hodnika I. typographus (dorsalno) 

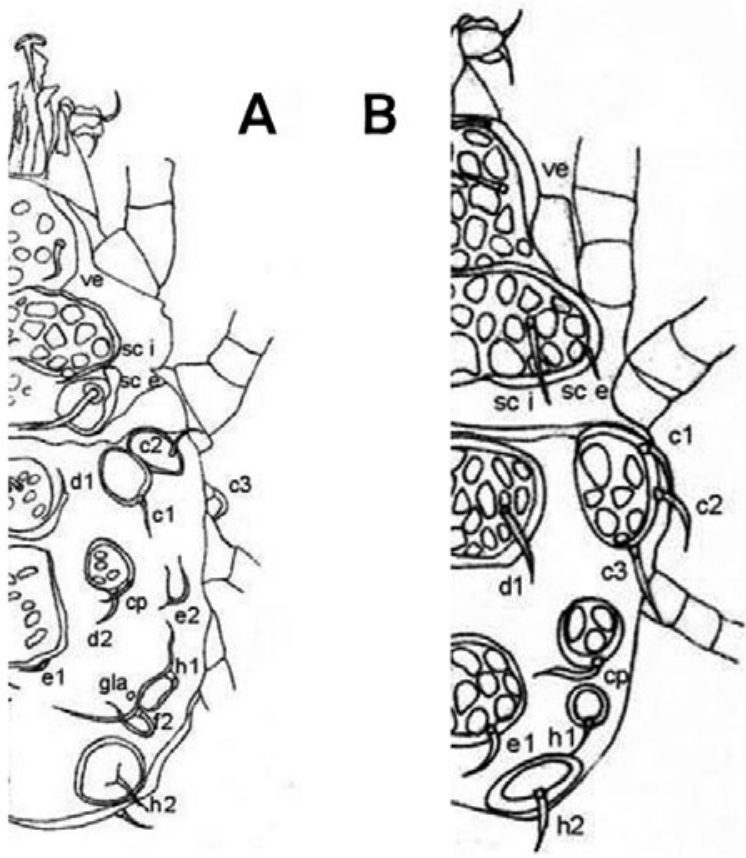

Figure 7: Free living nymphs of Histiostoma ovalis. A: protonymph in dorsal view, B: larva in dorsal view

Slika 7: Slobodno živuća nimfa Histiostoma ovalis. A. protonimfa dorzalno, B: larva dorzalno

nication, W. Magowski) and the fact that Histiostoma sp. carried large numbers of fungus spores. Both factors might harm the productivity of Ips typographus and I. cembrae.

\section{ACKNOWLEDGEMENTS}

\section{ZAHVALE}

We thank A. Garonna (Universita' degli Studi di Napoli Federico II) for his useful critcal comments to our manuscript. S. Wirth also thanks B. OConnor (university of Michigan, USA) for helpful general discussions about Histiostoma piceae. The latter author and $\mathrm{O}$. Weis are grateful tot he Croatian Forestry Research Institute in Jastrebarsko (central Croatia) for being hosted in in 2012.

The authors wish additionally to thank Anamarija Popovic and Željko Kauzlarić, Delnice, Hrvatske šume d.o.o., Croatia, for their help in beetle sampling.

S. Wirth and O. Weis are grateful to N. Lacković for guiding them to bark beetle areas.

This work was part of the DAAD project „PPP Kroatien Kennziffer 56266353".

We are grateful to R. A. Norton (ESF, New York, USA) for his determination of Neoliodes sp. on that genus level and W. Magowski (Uniwersytet im. A. Mickiewicza in Poznan, Poland) for his identification of Iponemus gaebleri and his informations about the biology of this mite.

The present research was supported in part (research about the morphology of juvenile stages oft he Histiostomatidae)by the grant from the Russian Science Foundation tot he Tyumen
State University, No. RSF 16-14-10109 with the title „Mites associated with bark beetles of main forest-forming coniferous trees of Western Siberia“. The grant covered extensive collecting of mites in Siberia and the Far East of Russia and rearing them in the laboratory conditions in Tyumen.

In memory to J. C. Moser, who was an excellent mentor to S. Wirth and M. Pernek and who died on 26 August 2015. He was an important precursor for the studies of mite-bark beeleassociations.

\section{REFERENCES LITERATURA}

- Boss, G. D., T. O. Thacher, 1970: Mites associated with Ips and Dendroctonus in southern Rocky Mountains: with special reference to Iponemus truncatus (Acarina: Tarsonemidae). Rocky Mountain Forest and Range Experiment Station, Forest Service, U.S. Dept. of Agriculture, 1-7, Fort Collins.

- Griffiths D. A., W. T. Atyeo, R. A. Norton, C. A. Lynch, 1990: The idiosomal chaetotaxy of astigmatid mites. J of Zool, 220:132, Annapolis.

- Kinn D.N., 1984: Life Cycle of Dendrolaelaps neodisetus (Mesostigmata: Digamasellidae), a Nematophagous Mite Associated with Pine Bark Beetles (Coleoptera: Scolytidae). Environ Entomol, 13(4):1141-1144, Annapolis.

- Koller L., S. Wirth, G. Raspotnig, 2012: Geranial-rich oil gland secretions: a common phenomenon in the Histiostomatidae (Acari, Astigmata)?. Int J o Acarol, 38(5):420-426.

- Lindquist E. E., 1969: Mites and regulations of bark beetle populations. U: Akademiai Kiado, Proceedings of the 2nd International Congress of Acarology, Publishing house of the Hungarian Academy of Sciences, 389-399, Budapest.

- Moser, J. C. 1975. Mite predators of the southern pine beetle. Annals of the Entomological Society of America 68: 1113-1116.

- Moser J. C., 1995: Mites associated with forest insects. Willamette Institute for Biological Control, Inc., Monroe, OR.

- Norton R., 1980: Observations on phoresy by Oribatid mites (Acari: Oribatei). Int J Acarol, 6(2):121-130.

- Penttinen R., H. Viiri, J.C. Moser, 2013: The mites (Acari) associated with bark beetles in the Koli National Park in Finland. Acarologia, French National Institute for Agricultural Research, 53(1): 3-15, Montpellier.

- Pernek, M, B. Hrasovec, D. Matosevic, I. Pilas, T. Kirisits, J.C. Moser, 2008: Phoretic mites of three bark beetles (Pityokteines spp.) on Silver Fir. J. Pest. Sci., 81: 35-42.

- Pernek M., S. Wirth, S. R. Blomquist, D. N. Avtzis, J. C. Moser, 2012: New associations of phoretic mites on Pityokteines curvidens (Coleoptera, Curculionidae, Scolytinae). Cent Eur J Biol, 7(1): 63-68.

- Scheucher R., 1957: Systematik und Okologie der deutschen Anoetinen. Beitrage zur Systematik und Okologie mitteleuropaischer Acarina, 1: 233-384.

- Stauffer C., F. Lakatos, G. M. Hewitt, 1997: The phylogenetic relationships of seven European Ips (Scolytidae, Ipinae) species. Insect Mol Biol, Royal Entomological Society, 6(3): 233-240, St Albans.

- Wirth, S., 2004: Phylogeny, Morphology and habitats of the Histiostomatidae (Astigmata). Proceedings of the V Symposium of 
the European Association of Acarologists. Phytophaga, 14:389407.

- Wirth S., 2009: Necromenic life style of Histiostoma polypori (Acari, Histiostomatidae). Experimental and Applied Acarology, 49(4):317-327.

- Wirth S., M. Pernek, 2012: First record of the mite Histiostoma ulmi in silver fir and indication of a possible phoretic dispersal by the longhorn beetle Acanthocinus reticulates. Šumar list, 1112:597-603.

- Wirth S., A. P. Garonna, 2015: Histiostoma ovalis (Histiostomatidae, Acari) associated with Ips sexdentatus (Scolytinae, Curculionidae, Coleoptera): ecology and mite redescription on the basis of formerly unknown adults and nymphs. Int J Acarol, 41(5):415-428.

\section{Sažetak}

Na nekoliko lokacija u Hrvatskoj (Nova Gradiška, Koprivnica, Gospić i Jastrebarsko) sa različitih vrsta drveća (Picea abies, Larix decidua i Pinus sylvestris) sakupljani su različiti stadiji ariševog potkornjaka, Ips cembrae i smrekinog pisara, Ips typographus te supstrat iz njihovih hodnika u svrhu sakupljana i identifikacije foretičkih grinja. Izravno sa tijela potkornjaka determinirano je 4 vrsta grinja: Iponemus gaebleri (Tarsenomidae), Histiostoma piceae (Astigmata, Histiostomatoidea), Dendrolaelaps quadrisetus (Gamasina) i Urobovella sp. (Uropodidae). Iponemus gaebleri bila je najčešća nađena vrsta kod obiju vrsta potkornjaka.

Tri druge vtrste sakupljene su izravno iz hodničkih sustava. Istraživana su i mjesta spajanja foretičkih grinja s potkornjacima. Iponemus gaebleri i $D$. quadrisetus tako se najčešće nalaze na obronku zadka, dok se foretičke deutonimfe porodice Histiostomatidae obično nalaze na ventralnoj strani prsišta. Statističkom anlizom potvrđen je jasna preferencija I. gaebleri na I. cembrae. Mladi još nezreli kukci Ips cembrae, koji izlaze iz materinjih hodnika nose signifikantno više foretičkih grinja nego roditeljski. Ženke neidentifcirane vrste roda Histiostoma nađene su u hodnicima I. typographus. Grinje su uglavnom bile pokrivene s većim brojem neidentificiranim sporama gljiva iz skupine Ascomycota (Hypocreales).

U radu se daje dihotomski ključ za identifikaciju larvi i protonimfi za porodicu Histiostomatidae.

KLJUČNE RIJEČl: Coleoptera, Curculionidae, Scolytinae, Tarsenomidae, Histiostomatidae, Acari, Iponemus gaebleri, Histiostoma piceae, Bonomoia pini, ključ za larve i protonimfe za Histiostomatidae

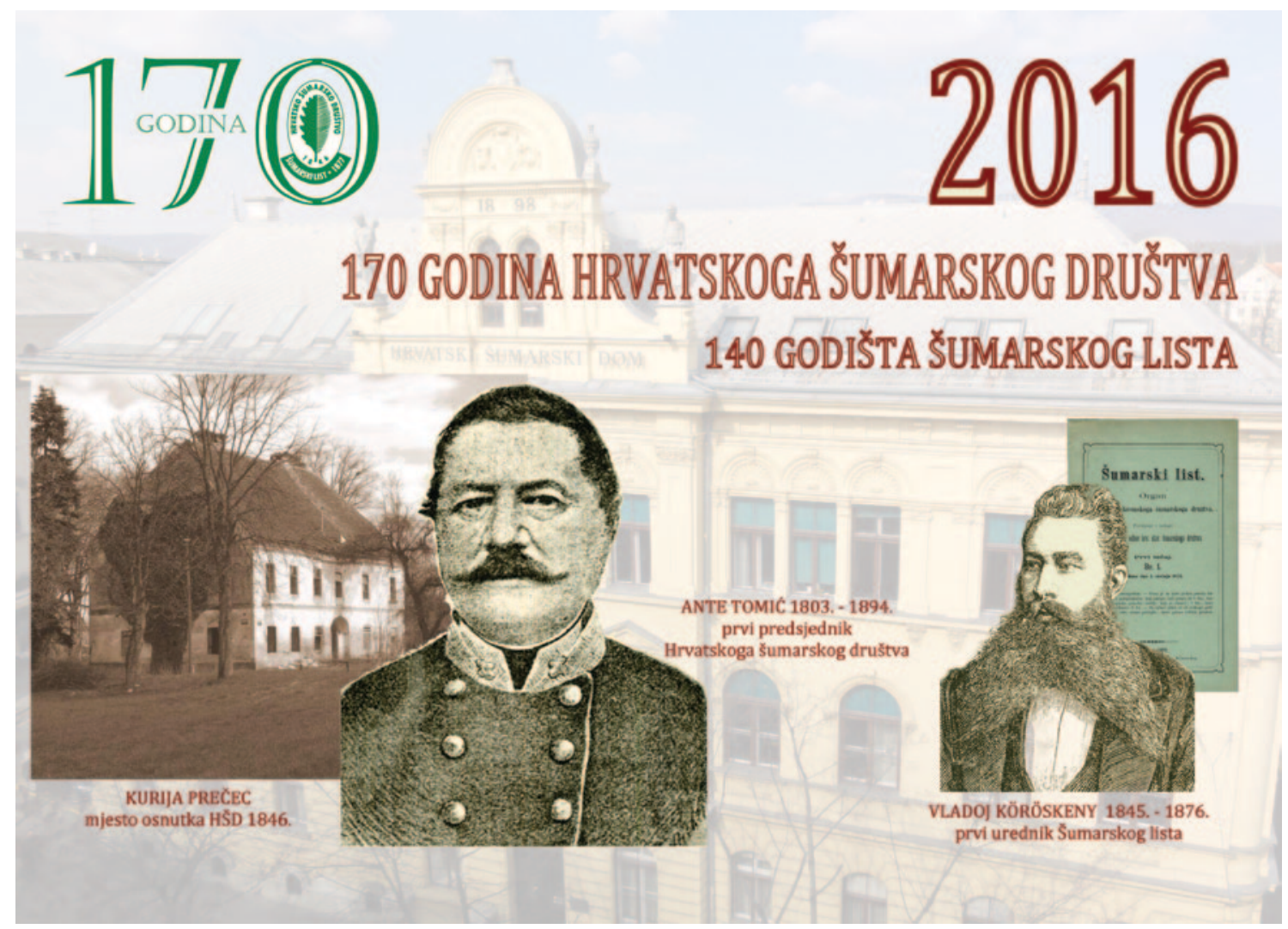

